\title{
ARAŞTIRMA/RESEARCH
}

\section{PROFESYONEL BİR MESLEK OLARAK EBELİK: LISSANSÜSTÜ PROGRAM ÖĞRENCILLERİ NE DÜŞÜNÜYOR? TEK DURUMLU BİR ÖRNEK OLAY ÇALIŞMASI}

\section{Damla KIZILCA ÇAKALOZ*}

\begin{tabular}{ccc}
\hline Alınış Tarihi/Received & Kabul Tarihi/Accepted & Yayın Tarihi/Published \\
01.08.2018 & 27.11 .2019 & 16.12 .2019 \\
\hline Bu makaleye atıfta bulunmak için/To cite this article: \\
Çakaloz DK, Çoban A. Profesyonel bir meslek olarak ebelik: Lisansüstü program öğrencileri ne düşünüyor? \\
Tek durumlu bir örnek olay çalışması. Anadolu Hemşirelik ve Sağlık Bilimleri Dergisi, 2019;22(4):239-248. \\
DOI: $10.17049 /$ ataunihem.450075
\end{tabular}

\section{Ayden ÇOBAN**}

\section{$\ddot{O} Z$}

Amaç: Bu araştırmanın temel amacı; ebelik lisansüstü programı öğrencilerinin profesyonel bir meslek olarak ebelik hakkındaki görüşlerini belirlemektir.

Gereç ve Yöntem: Nitel araştırma biçiminde desenlenen çalışmada, "tek durumlu örnek olay yöntemi" kullanılmıştır. Araştırmanın çalı̧̧ma grubunu, Adnan Menderes Üniversitesi Sağllk Bilimleri Fakültesi Ebelik Bölümü’nde lisansüstü eğitim gören ebeler oluşturmaktadır. Örneklem seçmede; amaçlı örneklem türlerinden "ölçüt dayanıklı örneklem” tekniği kullanılmıştır. Çalışmanın örneklemini 8 lisansüstü öğrencisi oluşturmaktadır. Veriler yüz-yüze gerçekleştirilen bireysel görüşmeler yoluyla "yart-yapılandırılmış görüşme tekniği” ile toplanmış ve değerlendirilmesinde, tüme varımsal içerik analizi tekniği kullanılmıştır.

Bulgular: Lisansüstü ebeler profesyonelliği sürekli eğitim içinde olma, gelişime açık olma, kanıt temelli uygulama yapma, bağımsız karar verebilme, etik davranma, empati yapma, bütüncül yaklaşım ve işini sevme olarak ifade etmişlerdir. Ayrıca farklı servislerde çalışmanın profesyonelleşme sürecini ve meslekte iş doyumunu olumsuz etkilediğini vurgulamışlardır. Öğrencilerin tamamı ebelik mesleğinin toplumda hak ettiği konumda olmadığını ve bu durumun servislerde farklı ĕgitim seviyelerinde çalışan ebelerin olmasından, görev tanımı, politika ve örgütlenme eksikliğinden kaynaklandiğını bildirmişlerdir. Ayrica örgütlenmenin meslek gelişimi için önemini bilmelerine rağmen çok az ögrenci derneğe üye olduğunu bildirmiştir.

Sonuç: Araştırma sonucunda, öğrencilerin profesyonelleşme kavramı açısından yeterince bilgiye sahip oldukları ancak fiziki ve sosyal koşulların eksikliği, yaşanılan zorluklar nedeniyle profesyonelleşmeyi devam eden bir süreç olarak gördükleri belirlenmiştir. Bu sonuçlar, ebelik mesleğinin toplumsal statüsünün geliştirilmesi ve çalışma şartlarının zorluklarına yönelik yeni düzenlemeler yapılması gerekliliğini düşündürmektedir.

Anahtar Sözcükler: Profesyonellik; Profesyonelleşme Süreci; Ebelik; Meslek

ABSTRACT

Midwifery as a Profession: What Do Postgraduate Students Think About? A One-State Case Study

Aim: The main objective of this research is to determine what the postgradute education students think about midwifery as a profession.

Methods: In this research figured by the qualitative research method, "one-state case study technique" has been used. The working group of this research consists of midwifes who are continuing their postgraduate education at Adnan Menderes University, Faculty of Health Sciences. "The criterion-based sampling" technique has been used when selecting the samples amongst the purposive sampling types. The samples of this research have been collected from 8 postgraduate students. The data have been collected by "semi-structured interview technique" applied via individual face-to-face meetings. The interviews have been recorded with the permission obtained from the participants, and the acquired data have been assessed by inductive content analysis technique.

Results: The postgraduate midwifes consider the midwifery as being in a continuous education, being open for improvement, handling prove-based applications, being able to make independant decisions, sticking to ethical rules, emphatizing, having an integrated approach and loving your job. Futhermore, they emphasised that working in different departments/areas of specialization negatively affects the professionalization process and job satisfaction. All students stated that the midwifery was not in a well-deserved place as a profession in society, and this situation was caused due to the midwifes who have different educational backgrounds, and due to the lack of mission, policy and organization. Moreover, although they know the importance of organization for professional development, few students reported that they are members of the association.

Conclusions: As a result of this study, it was determined that the students had enough information in terms of professionalization concept but they considered professionalization as an on-going process due to the lack of physical and social conditions, and difficulties they faced. These results make us think about the necessity of making new regulations to improve the social status of midwifery as a profession and to decrease the level of difficulties in working conditions.

Keywords: Professionality; Professionalization Process; Midwifery; Profession

*Sorumlu yazar: Aydın Adnan Menderes Üniversitesi, Sağlık Bilimleri Fakültesi, Ebelik Bölümü, (Arş. Gör.) ORCID: 0000-0001-5919-1364, e-posta: damla.kizilca@adu.edu.tr

**Aydın Adnan Menderes Üniversitesi, Sağlık Bilimleri Fakültesi, Ebelik Bölümü, (Prof. Dr), ORCID: 0000-0002-21892488, e-posta: ayden.coban@adu.edu.tr 


\section{GIIRIS}

Ebeler, çocuk sahibi olma sürecinde kadınların bakımında rol oynayan önemli bir meslektir ve mesleki yeterlilik, bilgelik, kişilerarası yetkinlik ve ebenin kişisel ve mesleki gelişimini içeren profesyonel bakım ebenin özünde mutlaka yer almalıdır (Hatem, Sandall, Devane, Soltani ve Gates,2008; Halldorsdottir ve Karlsdottir, 2011). Evrensel olarak kabul edilmiş bir tanım olmasa da Avusturalya profesyonel meslekler konseyinin tanımına göre profesyonel; yüksek etik standartlara bağlı ve kendi ayakları üzerinde durabilen, toplum tarafindan kabul edilen, yaygın olarak tanınan yüksek düzeyde eğitim ve öğretimden alınan özel bilgi ve becerilere sahip olan ve bu bilgi ve becerilerini başkalarının çıkarları doğrultusunda kullanmaya hazır olan birey olarak ifade edilmiştir. Bu tanımın özünde, toplumun refahı, sağlığ 1 ve güvenliği öncelikli olmalıdır (Halldorsdottir ve Karlsdottir, 2011).

İlk çağlarda bilimsel uygulamalardan uzak usta çırak ilişkisiyle yürütülen ebelik mesleği, sağlık alanındaki değişimleri takip ederek gelişme kaydetmiş, bilim ve sanatı etik değerler ile birleştirip yorumlayarak sağlık meslekleri içinde profesyonel bir disiplin olarak yerini almıștır (Sert, Erkal ve Tuna Oran, 2014; Arslan, Karahan ve Çam, 2008). Ayrıca son zamanlarda hız kazanan bilimsel çalışmalar; ebelerin kendilerini sürekli geliştiren, yeniliklere açık, entelektüel, araştırmacı, sorumluluk sahibi, lider, sosyal iletişimi yüksek gibi özellikleri kazanmalarına neden olmuş ve böylece ebeler profesyonelliğe giden yolda ilerlemişlerdir (Adıgüzel, Tanrıverdi ve Sönmez Özkan, 2011; Ünsar, Akgün Kostak, Kurt ve Erol, 2011). Ancak yaklaşık yüz elli yıllık bir dönem boyunca ne hemşireler ne de ebeler mesleki uygulamalarda yeterli otoriteye sahip olmadığı ve tıp mesleği tarafından denetlendikleri için klasik anlamda tam bir mesleki statü kazanamamıştır (Cant, Watts ve Ruston, 2011; Herdman, 2012; Altıok ve Üstün, 2014; Gönç, 2015). İngiliz ebe Bluff ve Holloway yaptıkları çalışmada ebelerin hastanelerde doğum yapan kadına değil, doktorlara yardımcı olduğunu iddia etmişlerdir. Bu şekilde çalışan ebelerin kötü bir örnek oluşturduğunu, uluslararası ebeler birliğinin amaçlarından farklı bir ebelik kültürü oluşturup, kadınların gebelik ve doğum sürecindeki ihtiyaçlarını karşılamadıklarını belirtmiştir (Bluff and Holloway, 2008).

Tarihsel olarak ebeler, ebeliğin tanımlanmasında ve diğer sağlık disiplinlerinden mesleği ayrıştırmakta güçlük yaşamışlardır
(Sabancıoğulları ve Doğan, 2012). 1990'lı yılların sonlarına doğru, hemşirelik ve ebelik tarafindan kullanılan profesyonelleşme stratejilerinin yeniden gözden geçirilmesi gerektiği kabul edilmiştir. $\mathrm{Bu}$ yeni stratejiler doğrultusunda profesyonel ebe/hemşire; diştan yönetilen, formüle dayalı teknik prosedürleri uygulamaktan ziyade, problem çözme, krize müdahale edebilme yetkinliğine ve yetkisine sahip olan, eğitimli, sağlığı koruyucu ve geliştirici uygulayıcılar olarak tanımlanmıştır (Butler, Fraser ve Murphy, 2008; Cant, Watts ve Ruston, 2011). Ayrica, ebelik uygulamalarında insana saygı-önem, bütüncül bakım, otonomi, etik ve sosyal adalet kavramları giderek önemli olmaya başlamıştır (Reiger, 2008; Shaw ve Degazon, 2008). Bu vizyon ayn1 zamanda ebelerin rolünü önemli ölçüde genişletmiş ve bu bağlamda yeni ebe tıbbi prosedürler tarafından belirlenen şartlarda sadece doğumu yönetmekle kalmayacak aynı zamanda bakımına aktif olarak katılacaktır (Adams, 2006).

Literatürde profesyonelliğin oluştuğu düşünülen bileşenler, bilgi, eğitim ve öğretim, beceri, özerklik, değerler, etik ve ödül olarak tanımlanmıştır (Butler, Fraser ve Murphy, 2008; Winch, 2004). Ancak, özgürlüğü kısıtlayıcı farklı bir ideolojiye göre çalışan tıp mesleği tarafından denetlenmeleri gibi ebelik mesleğinin profesyonelleşmesi sürecinde yaşanan zorluklar ve geleneksel uygulamalara dayalı eğitim sistemi nedeniyle yar1-profesyonel meslek olarak kategorize edilmiştir (Keeling and Templeman, 2013). Bu görüşten yola çıkarak planlanan bu çalışmanın temel amaci; profesyonelleşme sürecinde öne çıkan bazı konularda ebelik mesleğini değerlendirerek ebelik lisansüstü programı öğrencilerinin profesyonel bir meslek olarak ebelik hakkındaki görüşlerinin derinlemesine incelenmesidir.

Araştırmada bu temel amaç doğrultusunda aşağıdaki sorulara yanıt aranmıştır;

- Ebelik lisansüstü öğrencilerinin mesleğe yönelim nedenleri nelerdir?

- Ebelik mesleğinin toplumsal statü ve algısı hakkındaki düşünceleri nelerdir?

- Profesyonel bir meslek olarak ebelik mesleğinin durumunu nasıl değerlendirmektedir?

- Ebelik mesleğinin ülkemizdeki eğitimi ve mevcut akademisyenlerin katkısı konusundaki düşünceleri nelerdir?

- Türkiye'de ebelerin istihdam durumunun mesleğe etkisi nasıl değerlendirilmektedir?

- Ebelik mesleğinde örgütlenme hakkındaki görüşleri nelerdir? 


\section{GEREÇ VE YÖNTEM}

Araştırmanın Türü: Araştırmada, ebelik lisansüstü programı öğrencilerinin profesyonel bir meslek olarak ebelik hakkındaki görüşlerini derinlemesine incelemek amaciyla nitel araştırma yöntemlerinden "tek durumlu örnek olay yöntemi” kullanılmıştır.

Durum çalışması güncel bir olguyu kendi gerçek yaşam çerçevesi içinde çalışan, sınırların kesin hatlarıyla belirgin olmadığ 1 ve birden fazla kanıt ya da veri kaynağının mevcut olduğu durumlarda kullanılan görgül bir araştırma yöntemidir. Ayrıca durum çalışmasının "nasıll" ve "niçin" sorularını temel alan, araştırmacının kontrol edemediği bir olgu ve olayı derinliğine incelemesine olanak veren araştırma yöntemi olduğunu söylemek mümkündür (Yıldırım ve Şimşek, 2016).

Olay, bir kişi, bir grup, bir bölüm, bir süreç, bir toplum veya sosyal hayatın herhangi bir birimi olabilir. Olay ile ilgili tüm veriler toplanır ve tüm ulaşılabilir veriler olaya göre düzenlenir. Farklı insanların deneyimleri ayraç içine alınır, analiz edilir ve olgunun (fenomenin) gerçeğini tanımlamak için karşılaştırılır. Durum çalışması tek bir olayın çeşitli olgularla ilişkilendirilmesi ile araștırılan verilere bütüncül bir nitelik kazandırır (Yıldırım ve Şimşek, 2016; Merriam, 2013).

Araştırmanın Yeri ve Örneklemi: Araştırmanın verileri Adnan Menderes Üniversitesinde lisansüstü eğitim gören ebelik bölümü öğrencilerinden Mart-Mayıs 2017 tarihleri arasında toplanmıştır. Araştırmanın örneklemine, amaçlı örneklem türlerinden "ölçüt dayanıklı örneklem" tekniği ile belirlenen 8 lisansüstü ebelik öğrencisi dahil edilmiştir. Örneklem büyüklüğü nitel araştırma yaklaşımına, seçilen örneklemin çeşitliliğine ve katılımcının yeterli bilgi verme durumuna göre değişir bu nedenle örneklem büyüklüğünün belirlenmesinde için belirlenmiş bir kural yoktur. Ayrıca durum çalışmasında bir birey tek başına araştırma örneklemini oluşturabilir (Erdoğan 2015; Karataş 2015).

Veri Toplama Araçları: Araştırma verileri öğrencilerin profesyonel ebelik hakkındaki görüşlerini içeren soruların yer aldığı yarı yapılandırılmış görüşme formu ve ses kayıt cihazı ile toplamıştır. Görüşme formunda araştırmanın amacina uygun 11 soru bulunmaktadır. $\mathrm{Bu}$ sorulardan 2'si giriş sorusu, 8'i temel sorulardır. Görüşme soruları araştırmacı tarafından literatür taranarak hazırlanmıș, konuyla ilgili bir nitel araştırma uzmanı tarafindan değerlendirilmiştir(Adams, 2006; Andrews,
Brodie, Andrews, Hillan, Gail Thomas, Wong ve ark, 2006; Reiger, 2008; Cant, Watts ve Ruston, 2011; Halldorsdottir ve Karlsdottir, 2011; Alt1ok ve Üstün, 2014; Gönç, 2015; Atasoy ve Ermin, 2016; Bilgin, Kocabey, Yeşilyurt ve Öztürk, 2017). Görüşme formunun anlaş1lırlığ 1 ve uygulanabilirliğini geliştirmek için iki lisansüstü ögrencisi ile görüşülerek ön uygulama gerçekleştirilmiştir. Gerekli düzenlemeler yapıldıktan sonra, ön uygulama kapsamına alınan öğrenciler araştırma örneklemine dâhil edilmemiștir.

Verilerin Toplanması: Araştırma verileri ebelik alanında doktora eğitiminin yeterlik aşamasında olan, niteliksel araştırma konusunda eğitim ve deneyimi olan birinci araştırmacı tarafından yüz-yüze gerçekleştirilen bireysel görüşmeler yoluyla "yarı-yapılandırılmış görüşme tekniği" ile toplanmıştır. Veriler toplanmadan önce araştırmanın amaciyla beraber araştırmaya dâhil edilen lisansüstü öğrencilerine araştırma hakkında bilgi verilmiş, sözlü izinleri alınmıştır. Görüşmeler lisansüstü öğrencilerinin rahat iletişim kurabileceği düşünülen boş bir sinıfta yüz yüze yapılmıştır. Yapılan görüşmeler yaklaşık 25 dakika sürmüştür. Yarı yapılandırılmış görüşmeler önce ses kayıt etme özelliği olan cep telefonuna kaydedilmiştir. Görüşmeler bilgisayar ortamına aktarildıktan sonra, tekrar dinlenerek yazılı hale getirilmiştir. Toplam 35 sayfa ham görüşme metni elde edilmiştir.

Verilerin Analizi: Elde edilen verilerin analizinde, tüme varımsal içerik analizi tekniği kullanılmıştır. Verilerin çözümlenmesinde öğrencilerin ses kayıtları kelime kelime metin haline getirilmiş; Microsoft Word ortamında ham veri dokümanı oluşturulmuştur. Verilerin analizinde veriler satır satır okuma tekniği ile birkaç kez okunmuş, sonra tematik kodlamaya geçilmiş ve kodlar araştırmacılar (2 kişi) tarafından sınıflandırılmıştır. Benzer kodlardan kategoriler ve temalar oluşturulmuştur. $\mathrm{Bu}$ araştırmanın tasarlama aşamasında yardımlarını esirgemeyen Adnan Menderes Üniversitesi Eğitim Fakültesi Öğretim Üyesi Doç. Dr. Ruken Akar Vural'a, teşekkür ederiz.

Araştırmanın Sinırlılıkları: Nitel araştırmalar kesin ve genellenebilir sonuçlar ortaya koymayı amaçlamamaktadır. Ancak olay ve olgulara dâhil derinlemesine betimleme ve yorumlama yapmamıza yardımcı olacak öznel sonuçlar sağlayacak örnekler, açıklamalar ve yaşantılar ortaya koyabilir. Sonuçlar sadece incelenen grubu yansıtır bu nedenle bu çalışma için de en büyük sınırlılık genellemenin 
yapılamamasıdır (Erdoğan, Nahcivan, Esin, Coşansu ve Seçginli, 2014).

Araştırmanın Etik Boyutu: Araştırmanın yapılabilmesi için görüşmenin başlangıcında katılımcılara araştırma hakkında bilgi verilerek sözlü izinleri alınmıştır.

\section{BULGULAR VE TARTIŞMA}

Kadınların Tanıtıcı Bilgileri

Araştırma örneklemine dâhil edilen 8 öğrencinin mezun oldukları ve devam ettikleri program ve mesleki deneyimleri ile ilgili verileri aşağıda özetlenmiştir (Tablo 1).

Tablo 1. Araştırmaya Katılan Lisansüstü Öğrencilerinin Özellikleri

\begin{tabular}{cllc}
\hline $\begin{array}{c}\text { Kişi } \\
\text { No }\end{array}$ & \multicolumn{1}{c}{$\begin{array}{c}\text { Mezun Olduğu Lisans } \\
\text { Programı }\end{array}$} & $\begin{array}{c}\text { Eğitime Devam Ettiği Yüksek } \\
\text { Lisans Programı }\end{array}$ & $\begin{array}{c}\text { Mesleki } \\
\text { Deneyim }\end{array}$ \\
\hline 1 & Adnan Menderes Üniversitesi & Adnan Menderes Üniversitesi & 4 \\
2 & Adnan Menderes Üniversitesi & Adnan Menderes Üniversitesi & 2 \\
3 & Adnan Menderes Üniversitesi & Adnan Menderes Üniversitesi & 2 \\
4 & Firat Üniversitesi & Adnan Menderes Üniversitesi & 3 \\
5 & Süleyman Demirel Üniversitesi & Adnan Menderes Üniversitesi & 7 \\
6 & Adnan Menderes Üniversitesi & Adnan Menderes Üniversitesi & 2 \\
7 & Balıkesir Üniversitesi & Adnan Menderes Üniversitesi & 5 \\
8 & Adnan Menderes Üniversitesi & Adnan Menderes Üniversitesi & 4 \\
\hline
\end{tabular}

Görüşmelerden elde edilen veriler 6 ana tema altında toplanmıştır;

- Ebelik lisansüstü öğrencilerinin mesleğe yönelim nedenleri

- Ebelik mesleğinin toplumsal statü ve algis1

- Profesyonel bir meslek olarak ebelik mesleğinin durumu

- Ebelik mesleğine ilişkin ülkemizdeki eğitimin durumu ve mevcut akademisyenlerin katkısı

- Türkiye'de ebelerin istihdam durumunun mesleğe etkisi

- Ebelik mesleğinde örgütlenme

\section{Mesleğe Yönelim Nedenleri}

Çalışmada, ebelik bölümü lisansüstü programına devam eden 8 öğrenciye "bu lisans programını" nasil tercih ettikleri sorulmuş ve verdikleri yanıtlar incelenmiştir. Öğrencilerin mesleki tercih konusunda, yarısının istekli olarak geri kalan yarısının ise isteksiz biçimde yöneldiğini görmekteyiz. İsteksiz olarak mesleğe yönelenlerin tamamı "aileleri tarafindan" mesleğe yönelttiklerini belirtmişlerdir. İsteksiz olarak gelenlerin tamamı istihdam, iş garantisi ve mesleki olanaklar nedeniyle bu mesleğe tercihte bulunduklarını vurgulamışlardır. İstekli gelenlerin istihdam ve iş olanağ 1 vurgusu yapmaması dikkat çekicidir. Ebelik lisansüstü öğrencilerinin bazıları konuyla ilgili şu görüşleri ifade etmişlerdir:

"Ben hep ögretmen olmak istedim ama tercih zamanında ailemle birlikte ögretmen olma fikri değişti ve ebeliğe yönlendirildim. Annem istedi. Sağlığın daha kolay iş imkânı olmasından dolayı benim de hoşuma gitti tabi" (Ö4)

"Bu mesleği ailemin isteği ile seçtim. Annem de babam da atamalar kolay olduğu için seçmemi istediler. Askeri okul istiyordum ben. Ama şu an mesleğimi seviyorum." (Ö8)

Ebelik öğrencileri üzerinde yapılan çalışmalarda da benzer şekilde mesleğin tercih sıralamasına göre alt dilimlerde olduğu ve mesleği tercih edenlerin aile isteği ve iş bulma imkânının kolay olması sebebiyle seçtikleri görülmektedir (Yurtsal, Biçer, Duran, Şahin, Arslan ve Yavrucu, 2014; Kostak, Akarsu ve Ergül 2012; Bilgin ve Ocakç1, 2011; Derya Beydağ, Gündüz ve Özer 2008). Bir mesleğin profesyonellik düzeyi o mesleğin tercih edilmesindeki ilk nedenler arasındadır. Ancak bu sonucun mesleğin toplumda iş bulma garantili meslek olarak algilanmasından ve mesleği tercih eden öğrencilerin özerklik düzeyindeki zayıflıktan kaynaklandığı düşünülmektedir.

\section{Ebelik mesleğinin toplumsal statü ve algisı}

Çalışmaya katılan öğrencilere ebelik mesleğine ilişkin çevredeki kişilerin ebelik mesleğini nasıl algıladıkları ve ebelik mesleğinin toplumsal statüsü hakkındaki görüşleri sorulmuş ve yanıtları incelenmiştir. Öğrenciler ebelik mesleğinin toplum tarafindan zor bir meslek olarak algılandığını $(\mathrm{n}=5)$ ve çoğunlukla hemşirelik mesleği ile karıştırıldığını $(n=4)$ diğer yandan ebelik mesleğinin kutsal bir meslek olarak 
görüldüğünü $(n=3)$ ifade etmişleridir. Bu veriler ile ilgili bazı ifadeler şunlardır:

"Valla iki kısım var açıkçası. Bir tanesi bu mesleğin çok kutsal olduğunu ve ebelik mesleğinin çok zor bir iş olduğunu söyleyen grup var. Bir grupta daha mesleği mahalle arasinda yapılan eğitimsiz ebelerin yaptığ mesleğe benzeten hatta benzettikleri için daha düşük görenler var. Ama genel olarak ebelik mesleğinin zor bir meslek olduğunu, değer biçmek gerekirse diğer sağllk mensuplarına ve iş alanlarına göre daha düşük seviyede olduğunu düşünüyorlar." (Ö1)

"Tepkiler çok farkl gerçekten. "hemşire misin?" diyorlar. Hayır, ebeyim dediğimde ise "hil, tamam" deyip susuyorlar. Sanki ebe olunca farklısın. Eğitimde ise yolda biriyle karşılaştım bir gün 'ebeliğin okulu da mı var. Ne gerek var' tepkisini aldım. Birde sağlık alanında olduğum için "iyi yapmışsın bu mesleği seçmişsin, çok kutsal bir meslek" diyen de çok oldu. Farkl farklı anlamsız tepkiler var." (Ö4)

Ebelik mesleğinin toplumsal statüsüne ilişkin görüşleriyle ilgili olarak görüşülen öğrencilerin tamamı $(\mathrm{n}=8)$ mesleğin toplumda hak ettiği konumda olmadığını bildirmiştir. Ögrenciler bu durumun servislerde farklı eğitim seviyelerinde çalışan ebelerin olmasından $(\mathrm{n}=5)$, görev tanımı( $\mathrm{n}=3)$, politika $(\mathrm{n}=2)$ ve örgütlenme eksikliğinden $\quad(n=2)$ kaynaklandığını ifade etmişleridir. Ebelik lisansüstü öğrencilerinin bazıları konuyla ilgili şu görüşleri ifade etmişlerdir:

"Toplumda hak ettiğimiz konumda değiliz. Eğitimde farklılık çok olduğu için yardımcı eleman olarak bakıllyor. Ve hak ettiğimiz konumda olmadiğımızı düşünüyorum, eğitimle bu durum desteklenmeli. Liseden mezun bir ebeyle üniversite mezunu ebe arasinda bir fark olmall." (Ö7)

"Gerektiğinden daha az olduğunu düşünüyorum ebelik mesleğinin statüsünün toplumsal açıdan. Bakıldığında diğer ülkelerde ebelik mesleğine verilen önem çok çok fazla fakat ülkemizde uygulanan politikalar gereği olsun meslek adına profesyonelliğin, meslek tanımının tam olmamasi nedeniyle statüsü şu an olması gerekenden çok daha alt seviyede yer allyor. Yani klsaca ülkemizde toplumsal açıdan ebelik mesleğini yücelten ya da tam olarak anlatan bir politika ya da organizasyon olmadığından olması gerektiği yerde değil." (Ö1)

$\mathrm{Bu}$ konu ile ilgili yapılan araştırmalarda benzer şekilde öğrenciler ebelik mesleğinin toplumsal statüsünün düşük olduğunu (Yılmaz, Şen ve Demirkaya 2014), ve toplumun ebeliğe karş1 olumsuz yargıları olduğu (Yurtsal, Biçer, Duran, Şahin, Arslan ve Yavrucu 2014) bildirilmiştir. Dinç, Söğüt ve Cangöl (2017) ve Pınar, Yıldırım, Duran, Cesur, Üstün ve Güler'in (2014) çalışmalarında ise öğrenciler toplumun ebeliğe bakış açısını kısmen olumlu bulduğunu bildirmiştir. Mesleğin toplumda hak ettiği konumda olmaması, algının olumsuz olması öğrencilerin mesleki kimlik karmaşası yaşamalarına ve motivasyonlarının olumsuz yönde etkilenmesine neden olduğu düşünülmektedir. Bir ebenin toplumdaki bireylere verdiği bakımın standartları ve ebenin davranış şekli bireylerin akıllarındaki ebelik imajını etkilemektedir. Ebeliğin profesyonelleşmesinde rol oynayan değerler mesleğin toplum tarafindan kabul görülmesine ya da reddedilmesine neden olur. Bu nedenle ebelerin meslek etiğe ve görev tanımına uygun davranışlarda bulunması; bakım verdiği bireyin ve toplumun güveninin kazanılmasına, meslek değerlerinin korumasına olanak sağlar (Dinç, Söğüt ve Cangöl 2017; Pınar, Y1ldırım, Duran, Cesur, Üstün ve Güler 2014; Dinç, Kaya ve Şimşek 2007).

\section{Profesyonel bir meslek olarak ebelik mesleğinin durumu}

Çalışmanın örneklemini oluşturan öğrencilere "mesleğinde profesyonel bir ebe nasıl davranmalıdır" diye sorulmuş ve verdikleri yanttları incelendiğinde ebeler profesyonelliği sürekli eğitim içinde olma $(n=5)$, gelişime açık olma( $(n=4)$, kanıt temelli uygulama yapma $(n=2)$, bağımsız karar verebilme $(\mathrm{n}=2)$, etik davranma $(\mathrm{n}=2)$, empati yapma $(\mathrm{n}=2)$, bütüncül yaklaşım $(n=2)$ ve işini sevme $(n=1)$ olarak ifade etmişlerdir. Ayrıca öğrencilerin tamamına yakını $(n=6)$ kendisini profesyonel bir ebe olarak yeterli bulmadığını belirtmişlerdir. Bu veriler ile ilgili bazı ifadeler şunlardır:

"Profesyonel ebelik zaten nedir? Öğrendiğini uygulamaktır. Doğru olanı son literatüre göre son araştırmalara göre doğru olanı uygulamaktır. Bence profesyonellik aynı zamanda da hastaya bütüncül yaklaşım sadece tedaviye odakl değil daha çok psikolojik olarak ta katılıp hastaya bütüncül yaklaşım olması. Kisaca dediğim gibi bütüncül yaklaşım birazclkta empati kurma bence kesinlikle birazcık ta işini sevme." (Ö2)

"Krizi yönetebilmeli ilk başta. Aile să̆gl̆ğ merkezinde çalışıyoruz mesela yeni aşı çıkıyor bunu yönetemiyoruz nereye soracağımızı bile bilmiyoruz. Ebeler kendini geliştirmiyor. Eğitim önemli. Araştırmall geliştirmeli. Kendilerini gelişstirmek için mesela yüksek lisans yapabilir 
okumall, araştırmalı. Kendimi çok yeterli bulmuyorum ama çalıştı̆̆ım yere göre profesyonelim." (Ö8)

Uluslararas1 Ebeler Konfederasyonu (ICM), dünya çapındaki ülkeleri temsil eden ebelik birliklerinin bir federasyonudur ve ebe tanımının geliştirilmesinde, ebelik uygulama kapsamının tanımlanmasında (temel yeterlilikler) liderlik rolü üstlenir. Ayrıca ülkelere ebelik birliklerinin kapasitesini güçlendirmeleri ve dünya çapında ebelik mesleğinin liderlerini geliştirmeleri konusunda yardım eder. Uluslararas1 Ebeler Konfederasyonu (2013)'na göre profesyonel bir ebe; klinik kararlarda özerk, mesleki etik değerler ve insan haklarına uygun olarak hareket eden, kanıta dayalı bakım standartlarına uygun hareket eden, sürekli eğitim içinde olarak bilgilerini güncelleyen, etnik köken ve dini inançtan bağımsız olarak bireylerin mahremiyetine ve geleneklerine saygılı, kadın, ailesi ve diğer sağlık çalışanlarıyla işbirliği içinde çalışan bireyler olarak ifade edilmiştir (International Confederation Of Midwives, 2016). Bizim çalışmamızda da lisansüstü ebeler profesyonelliğini benzer şekilde ifade etmişlerdir. Butler, Fraser ve Murphy (2008) ebelik öğrencileri ile ebelikte profesyonelliğinin en önemli yönlerini tartıştıkları nitel çalışmalarında profesyonelliği güvenli hizmet sunumu, doğru tutum, davranış ve iletişim becerilerine sahip olma olarak belirtmiştir. Byrom ve Downe (2010) fenomenolojik çalışmalarında iyi bir ebe olmak için gerekli olan unsurları bilgi, beceri ve uygulamalarda yetkinlik ve duygusal zekâ olarak ifade ettikleri kişilik faktörleri olarak vurgulamışlardır.

\section{Ebelik mesleğine ilişkin ülkemizdeki eğitimin durumu ve mevcut akademisyenlerin katkısı}

Çalışmada lisansüstü

öğrencilere ülkemizdeki ebelik eğitimi konusundaki düşünceleri sorulmuş, çoğunluğu $(n=5)$, ülkemizde aldıkları eğitimin yeterli olduğunu, lisansüstü eğitim programlarına sahip okulların olduğunu $(\mathrm{n}=4)$, ortak eğitim müfredatı oluşturulduğunu ( $\mathrm{n}=3)$ ifade etmişlerdir. Ancak aldıkları eğitimden memnun olan öğrenciler $(n=3)$ eğitim araçlarının geliştirilmesi gerektiğini vurgulamışlardır. Ayrıca farklı üniversitelerin lisans eğitiminden mezun olan öğrenciler $(n=3)$ aldıkları eğitimi yeterli olmadığını düşünmektedir. Ebelik mesleğine mevcut akademisyenlerin katkısına yönelik öğrenciler somut bir cevap vermemişlerdir. $\mathrm{Bu}$ durum öğrencilerin çalışmanın yapıldığı üniversitede lisansüstü öğrenimlerine devam etmeleri nedeniyle akademisyen öğrenci hiyerarşisinin öğrencilerin cevap verme yetisini sınırlandırmış olabilir.

Ebelik lisansüstü öğrencilerinin bazıları konuyla ilgili şu görüşleri ifade etmişlerdir:

"Şu anda çekirdek müfredat oluşturuldu aslında. Tüm üniversitelerde ortak eğitim müfredatı var. Derslere içerikler aynı olmaya başladı. Bununla ilgi her yul toplantılar yapllyor. Yüksek lisans, lisans doktora programlarl var. $O$ yüzden ĕgitim alanında çok açı̆̆ımız yok ama uygulama ve pratik olarak gelişmemiz gerekiyor. Nedeni ise çok fazla ögrrenci var. Ĕ̈itim araçlarınin geliştirilmesi gerekiyor. Laboratuvar gibi çalışma ortamları artırılmall." (Ö1)

"Şöyle genel olarak ülke evet yeterli ve ben kendi okulumdan da çok memnunum çok iyi bir eğitim aldiğımızı düşünüyorum genel olarak sahaya çıktığımızda da yaz stajlarında falan bunu çok net görüyoruz yani sadece bunu söyleyebilirim yani ülke eğitiminde değil de kendi aldı̆̆ım ĕgitim güzel bir eğitim. Ancak verilen eğitimde kullanilan aletlerin eksiklerinin giderilmesi gerekiyor." (Ö3)

$\mathrm{Bu}$ konu ile ilgili yapılan araştırmalardan Atasoy ve Ermin (2016) öğrencilerin aldıkları eğitimi kısmen yeterli bulduklarını, Karadağ, Açıkgöz, Balcı, Ünsal, Kösgeroğlu, Kaya ve arkadaşları (2012) ise öğrencilerin eğitimlerinden memnun olma ve motivasyon düzeylerinin orta olduğu ve bunun nedenlerini interaktif eğitim yöntemlerinin yeterince kullanılmamas1, eğitimciden yeterli destek alınamaması ve geleneksel eğitim yöntemlerinin kullanılması olarak bildirilmiştir. Güner, Yurdakul ve Yetim (2015) Türkiye'de ebelik mesleğinin sorunlarına yönelik öğretim üyelerinin görüşlerini inceledikleri nitel çalışmada okul ve öğrenci sayısını fazla, beceri laboratuvarı ve uygulama alanlarını ise yetersiz olarak nitelendirmişlerdir. $\mathrm{Bu}$ durum ülkemizdeki ebelik okullarının fiziki koşullarının, eğitim ve eğitimciye yönelik yasal prosedürlerinin temel yeterlilik alanlarına göre yetersiz kalmasından kaynaklı olduğu düşünülebilir.

Ayrıca çalışmada farklı eğitim düzeyinde çalışan ebelerin olmasının uygulamalar üzerine etkisi sorulmuş, öğrencilerin tamamı $(\mathrm{n}=8)$ farklı eğitim düzeyinde çalışan ebelerin olması bakım ve uygulamaları çok etkilediğini, okulda öğrendikleri güncel ve kanıta dayalı bilgilere rağmen hastanelerde bu uygulamaları göremediklerini ve bu konuda ikilemde kalarak ebe ve hemşirelerle sorun yaşadıklarını 
belirtmişlerdir. Ayrıca lisans mezunu ebelerin pratik tecrübeye dayalı iş yaptığını, lisans mezunu ebelerin teorik bilgiye dayalı profesyonel bakış açısıyla çalıştıklarını ifade etmişlerdir. Bu veriler ile ilgili bazı ifadeler şunlardır:

"En fazla uygulamalarda tabiki. Örneğin doğum salonunda staja çıktı̆̆ımızda lise mezunu ebeler 'niye steril eldiven giydin ki? Normal eldivenlerden giyseydin, ben doğumda steril eldiven kullanmiyorum, ne gerek var.' tepkileri altyoruz. Ben kendimle de çelişiyorum o ebe hanımla çatışırsam doğumhaneye girmem zorlaşacak e doğru bildiğini yaptığın zaman zor durumda kallyorsun. Böyle sikintılar var. Uygulamayla ilgili ögrenilen bilgiler sahaya yansitılamiyor. Sahaya yansitılmadıktan sonra uygulamaların ögrenilen bilgilerin kongrede tartışılan konuların bir anlamı kalmıyor. Sahaya yansıması önemli.,"(Ö7)

"Farkl mesleki eğitim düzeylerinde olmak uygulamada gerçekten fark yaratıyor, yani lisans mezunu bir ebeyle lise çıkışlı bir ebenin şu farkı oluyor, lisans mezunu ebe işini teorisine uygun olarak uygulamaya çalışıyor, öğrendiklerini uygulamaya sokuyor daha profesyonel oluyor, bilgi düzeyi ve olayla bakış açısı sunabiliyor fakat lise mezunu ebenin de deneyimi çok oluyor bazen oda deneyimleriyle çalışıyor ama tabiî ki eğitimle mesleki gelişme sağlaniyor." (Ö5)

Seviğ, Başer, Güler ve Yurdakul'un (2008) ebe istihdamına ilişkin raporlarında ve Güner Yurdakul ve Yetim'in (2015) çalışmasında nitelik olarak yetersiz bölümlerin ve sağllk yüksekokullarında öğrenci alımının durdurulmasının uygun bir yaklaşım olacağı belirtilmektedir. Bu sonuçlar öğrencilerin mesleki uygulamalarını profesyonel düzeyde gerçekleştiremediğini göstermesi bakımından önemlidir. Ayrıca son dönemdeki (T.C. Resmi Gazete, 2014) mesleki düzenleme ile lise mezunlarına ebe unvanının verilmeyecek olmasının mesleği güçlendireceği söylenebilir.

\section{Türkiye'de ebelerin} istihdam durumunun mesleğe etkisi

Çalışmada lisansüstü öğrencilerine ebelerin Türkiye'deki istihdamı konusunda ne düşündükleri sorulmuş, öğrencilerin tamamı $(n=8)$ iş olanağının olduğunu ancak istihdamın yeterli olmadığını belirtmişlerdir. Ayrıca farklı uzmanlık alanlarında/servislerde çalışmanın profesyonelleşme sürecini ve meslekte iş doyumunu olumsuz etkilediğini vurgulamışlardır. $\mathrm{Bu}$ veriler ile ilgili bazı ifadeler şunlardır:

"Bir kere aile sağlı̆̆ elemanı adı altında çalıştırılarak zaten bizim profesyonelliğimiz elimizden alınıyor yani hastalar gözünde etkimiz kalmıyor. Farklı işler yaptırlliyor. Farklı kliniklerde çalışsak ta aynı şey sonuçta ben dediğim gibi 4 yll boyunca kadın doğum yeni doğan üzerine odaklanmışım. Ama ben gidip gözde gögü̈ste orda burada çalışacağıma ben orda sadece ne ögrenebilirim? Sifirdan eğitim almış gibi oluyorsun ama bir uzmanlık eğitimi değil. Usta çırak ilişkisine dönüyor profesyonelliğinde doğal olarak etkiliyor." (Ö2)

"Ebelerin farklı alanlarda çalışması beni çok hayal kırlklı̆̆ına uğratıyor. Mesela atanmak istiyorum ama sirf bu korkudan farklı bir bölümde çalışırım korkusundan atanmak istemiyorum. Bir göz servisinde çalışırsam mutlu olmam. Ë̆itimimi uygulayabileceğim yerde çalışmak istiyorum". (Ö4)

"Ben de işe başlarken sadece kendi mesleğimi yapmak istediğimi söyledim. Вunu söylememe rağmen çalıştırılmak istendim. Ama ben bunu ret ettim. Bilmediğim bir alan ve çalışmak istemediğimi söyledim. Hastalara yararımdan çok belki zararım dokunacak ve ben yaptı̆̆ım işten zevk almadan sadece para kazanmak için çalışmış olucam." (Ö6)

Türkiye İstatistik Kurumu (2017)'nin raporuna göre; işsizlik oranı \%10,9'dur. Sağlık sektörü \%9,6 ile işsizliğin en az olduğu üçüncü sektördür. İstatistiklere göre mesleğin iş olanağının yüksek olduğu bir gerçektir ancak çalışmamızla benzer şekilde Andrews, Brodie, Andrews, Hillan, Gail Thomas, Wong ve arkadaşlarının (2006) çalışmasında çalışılan kliniklerin mesleki rol ve profesyonellikte etkili olduğu ve birimler arasında farklılıkların olduğu belirtilmektedir. Karaçam ve Güler'in (2016) çalışmasında da yeni mezun ve öğrenci ebelerin, sadece doğum ve kadın sağlığı servislerinde değil birçok serviste çalıştırıldıkları, ebelerin hemşirelik görevlerini yaptığı ve ebelerin çalışma alanının hemşirelerden daha az olduğu sonuçlarına ulaşılmıştır. Yapılan çalışmalarda da ebelerin genel iş doyumlarının düşük olduğu belirlenmiştir. (Y1lmaz, Şen ve Demirkaya2014; Tekin Kaya ve Bilgin, 2015). Bu bulgu ebelerin profesyonelleşme sürecini etkileyen etmenler açısından değerlendirildiğinde önemli bir anlam ifade etmektedir

\section{Ebelik mesleğinde örgütlenme}

Çalışmaya katılan ebelerin tamamı $(n=8)$ ebelik mesleğinin gelişimi için örgütlenmenin önemli olduğunu ifade etmişlerdir. Ancak çok az lisansüstü öğrencisi $(n=2)$ derneğe üye olduğunu belirtmiştir. Ancak üye olanlarda derneğin çalışmasını yetersiz bulmaktadır. Bu konuda 
ebelerin çoğu $(n=6)$ derneklerini yurtdışı meslek örgütleri ile kıyaslayarak örgütün çalışmalarını ve yaptırım gücünü yetersiz bulmaktadır. Ebelik lisansüstü öğrencilerinin bazıları konuyla ilgili şu görüşleri ifade etmişlerdir:

"Kendi mesleğimin örgütüne üyeyim. Ama aktif olarak katılmadığım şeyler de var. Her kafadan bir ses çıkıyor. Mesleki örgütlerin iyi yürütüldüğ̈̈nü düşünmüyorum. Bireysel gidiyor her şey. Yurt dişı ile karşılaştırıldığında hep konuşuyoruz örgütlenme çok önemli bir adım mesleğin ileri gitmesi adına. Örgütlenme mesleğin korunmasına gelişmesine ilişkin çok önemli. Yurtdışında örgütlenme çok üst seviyede. Eğitimler girişimler planliyorlar. Bu örgütlenme hem mesleğin denetimini yaplyor hem mesleğin gelişmesi adına birçok eğitimler ve girişimler planllyorlar. Yani örgütleşmenin önemini algılamayan meslektaşlarımız bununla ilgili bir girişimde bulunmuyorlar. Bir şeyler yapmaya çalışsalar da bütünlük yok. Herkes ayrl telden çaltyorlar." (Ö1)

"Mesleki örgütlenme çok önemli yani meslekle ilgili sorunların çözümü noktasinda, mesleki gelişmeler sağlayabilmek açısında çok önemli, üye olmakta önemli, yaptırtm gücüne sahip olabilmesi için o derneğin. Bence her ebenin mesleğinin örgütlenmesi noktasinda çalışmalarını desteklesin desteklemesin üye olması gerektiğini düşünüyorum. Fakat ebelik mesleğinin örgütlenmesi çok kötü, derneğin üye sayısı çok az, ebeler de örgütlenme bilincinin düşük olduğunu düşünüyorum, bunu da eğitimle sağlayacağız bence, yani bana ne faydası olacak, bide ona aidat $m \imath$ ödeyeceğim ya da önemsememekten dolayı beklide kaynaklaniyor bu. Bir de ebeler derneğinin aktif çalışmamasından, etkin bir liderlerinin olmamasindan ve tanitımın yani amaçların hedeflerini ve derneğe üye olmanin öneminin insanlara yani meslektaşlarına iyi mesaj verememekten kaynaklaniyor bu bence." (Ö5)

Profesyonelleşme sürecinin önemli bileşenlerinden olan mesleki örgütlenme ebeler açısından oldukça zayıftır. Doğan Merih ve Arslan'ın (2012) çalışmasında hemşire ve ebelerin yalnızca üçte birinin (\%37.3) örgüt katılımının olduğu, örgütlenmenin yeterince olmamasının nedenleri ise mesleki bilinçbağlılı̆̆ın yeterince oluşturulamamasına ve etkin liderlerimizin olmamasına bağladıkları belirlenmiştir. Bilgin, Kocabey, Yeşilyurt ve Öztürk'ün (2017) çalışmasıyla benzer şekilde ebelerin çoğunluğunun mesleki örgütlenmenin gereğine ve profesyonelleşmenin mesleki örgütlenmeyi artırdığına inandığı ancak oldukça az bir çoğunluğun $(\% 26,8)$ Türk Ebeler Derneğine üye olduğu saptanmıştır. $\mathrm{Bu}$ bulgunun profesyonel meslek statüsünün iyileştirilmesi için örgüte üyelik durumunu engelleyen durumlara çözüm üretilmesi açısından önemli olduğu söylenebilir.

\section{SONUÇLAR VE ÖNERILER}

Araştırma sonucunda, öğrencilerin profesyonelleşme kavramı açısından yeterince bilgiye sahip oldukları ancak farklı servislerde çalışmanın profesyonelleşme süreci ve meslekte iş doyumu üzerine olumsuz etkileri olduğu belirlendi. Ayrıca mesleğinin toplumda hak ettiği konumda olmamas1, görev tanımı, politika ve örgütlenme eksikliği gibi zorluklar nedeniyle profesyonelleşmeyi devam eden bir süreç olarak gördükleri saptand.

$\mathrm{Bu}$ sonuçlara dayalı olarak;

- Ebelik mesleğinin benimsenmesi, bilinçli bir tercih yapılabilmesi için mesleğin tanıtımının tüm yönleriyle ele alınması, profesyonel kimlik gelişimlerini olumlu yönde geliştirmeleri için standart bir eğitim ve uyum programı oluşturulması, Mezun öğrencilerin bölümle ilgili olumlu duygularının mesleği seçme aşamasında olan öğrencilerle paylaşılması

- Ebelik mesleğinin toplumsal statüsünün geliştirilmesi, ebelik mesleği ile ilgili toplumda farkındalık oluşturulması için mesleki tanitımların yapilmasi, ebelerin toplumsal sorumluluk projelerinde yer almalarının sağlanması,

- Örgün ve hizmet içi eğitim programlarında ebelerin profesyonelliklerini geliştirmeye ve mesleğe uyum sağlamalarını sağlayıcı seminerler ve aktiviteler düzenlenmesi, profesyonelliğini geliştirmeye yönelik standart bir eylem planının oluşturulması

- Lisans eğitimine ilişkin sorunların çözümü için alt yapı açısından yetersiz olan bölümlerde gerekli iyileştirmelerin yapılması, klinik ve teorik eğitim sürecinde uygun öğretim stratejilerinin ve öğrenmeyi kolaylaştıran araç gerecin sağlanması,

- Çalışma şartlarının zorluklarına yönelik ebelerin karar verici rollerini güçlendirmesi için kanıta dayalı uygulamalara göre bilgi ve uygulamalarını güncellemelerin yapılması, farklı eğitim durumu ortadan kaldırılıp eşit ve etkin eğitim olanakları sağlanması,

- Ebelere meslek örgütü bilinci kazandırılmasına yönelik mesleki örgütün önemi, rol ve işlevlerine yönelik detaylı bilgi verilmesi, 
Anadolu Hemşirelik ve Sağlık Bilimleri Dergisi Journal of Anatolia Nursing and Health Sciences

örgütlerin amaç-faaliyetlerinin daha iyi tanıtılması, iletişim olanaklarının iyileştirilmesi

\section{KAYNAKLAR}

Adams J. An exploratory study of complementary and alternative Medicine in hospital midwifery: models of care and professional struggle. Complementary Ther in Clin Pract 2006;12(1): 40-7.

Adıgüzel O, Tanrıverdi H, Sönmez Özkan D. Mesleki profesyonellik ve bir meslek mensupları olarak hemşireler örneği. Yönetim Bilimleri Dergisi 2011; 9(2):239-59.

Altıok HÖ, Üstün B. Profesyonellik: Kavram Analizi. DEUHYO ED 2014,7(2), 151-5.

Andrews GJ, Brodie DA, Andrews JP, Hillan E, Gail Thomas B, Wong J, et. al.Professional Roles and Communications in Clinical Placements: A Qualitative Study of Nursing Students. Perception and Some Models for Prectice". Int J Nurs Stud 2006; 43(7):861-74.

Arslan H, Karahan N, Çam Ç. Ebeliğin Doğası ve Doğum Şekli Üzerine Etkisi. Maltepe Üniversitesi Hemşirelik Bilim ve Sanatı Dergisi 2008;1(2):54-9.

Atasoy I, Ermin C. Hemşirelik ve Ebelik Öğrencilerinin Mesleklerine Bakış Açısının İncelenmesi. Düzce Üniversitesi Sağlık Bilimleri Enstitüsü Dergisi 2016;6(2):83-91.

Bilgin Z, Kocabey MY, Yeşilyurt G, Öztürk D.Ebelerde Örgütlenme ve İş Doyumunun Belirlenmesi. HSP 2017;4(1):105-10

Bilgin Z, Ocakçı AF. Ebelik Öğrencilerinde Mesleki Güdülenme. Anadolu Hemşirelik ve Sağlık Bilimleri Dergisi 2011;14(3):40-6.

Bluff R, Holloway I. The efficacy of midwifery role models. Midwifery 2008; 24: 301-19.

Butler M, Fraser DM, Murphy RJL. What are the essential competencies required of a midwife at the point of registration? Midwifery 2008; 24: 260-9

Byrom S, Downe S. "She sort of shines": midwives' accounts of good midwifery and good leadership. Midwifery 2010; 26:126-37

Cant S, Watts P, Ruston A. Negotiating competency, professionalism and risk: The integration of complementary and alternative medicine by nurses and midwives in NHS hospitals. Social Science \& Medicine 2011; 72: 529-36.

Derya Beydağ KD, Gündüz A, Özer FG. Sağlık Yüksekokulu Öğrencilerinin Eğitimlerine Ve Mesleklerine Bakış Açıları, Meslekten Beklentileri. Pamukkale Tip Dergisi 2008;1(3):137-42.

Dinç A, Söğüt SC, Cangöl E. Ebelik Öğrencilerinin Mesleki Tercih Hakkında DüşünceleriCumhuriyet Üniv. Sağ. Bil. Enst. Derg 2017;(2)2:15-23

Dinç S, Kaya Ö, Simsek Z. Harran Üniversitesi Sağlık Yüksekokulu öğrencilerinin hemşirelik mesleği hakkındaki bilgi, düşünce ve beklentileri. Atatürk Üniversitesi Hemşirelik Yüksekokulu Dergisi 2007; 10(1):1-9.

Doğan Merih Y, Arslan H. Hemşire ve Ebelerin Mesleki Bilinç Örgütlenmeye Yönelik Görüşlerinin ve
2019; 22(4):239-248

DOI: $10.17049 /$ ataunihem.450075

ve örgütlenme bilincini sürdürebilecek etkin liderlerin belirlenmesi önerilebilir.

İş Doyumlarının Belirlenmesi. Hemşirelikte Eğitim ve Araştırma Dergisi 2012; 9(3):40-6

Erdoğan S, Nahcivan N, Esin N, Coşansu G, Seçginli S. Hemşirelikte Araştırma: Süreç, Uygulama ve Kritik. Erdoğan S, Nahcıvan N, Esin N, editörler. İstanbul: Nobel Tıp Kitabevi; 2014.p.131-64.

Erdoğan, S. Nitel araştırmalar: Hemşirelikte araştırma süreç, uygulama ve kritik. 1.Baskı. İstanbul: Nobel Tıp Kitapevi; 2015. p.131-64.

Gönç T. Türkiye'de Hemşirelik Mesleğinin Profesyonelleşmesi Sürecinde Gelişmeler ve Zorluklar: Sosyolojik Bir Değerlendirme. "İş, Güç" Endüstri İlişkileri ve İnsan Kaynakları Dergisi 2015; 17(4): 113-46.

Güner S, Yurdakul M, Yetim N. Türkiye'de Ebelik Mesleğinin Sorunlarına Akademik Bakışı Yansıtan Nitel Bir Çalışma. Yükseköğretim ve Bilim Dergisi 2015;5(1):80-7.

Halldorsdottir S, Karlsdottir SI. The primacy of the good midwife in midwifery services: an evolving theory of professionalism in midwifery. Scand J Caring Sci; 2011; 25: 806-17.

Hatem M, Sandall J, Devane D, Soltani H, Gates S. Midwife-led versus other models of care for childbearing women. Cochrane Database Syst Rev 2008; CD004667.

Herdman EA.Professions and Professionalism. HEAD 2012; 9(2): 3-7

International Confederation of Midwives. Essential competencies for basic midwifery. Global Standards, 2016.p.1-19.

Karaçam Z, Güler T.Yeni Mezun Ve Öğrenci Ebelerin Kendilerini Hemşire Olarak TanıtmaNedenleri. Ege Üniversitesi Hemşirelik Fakültesi Dergisi 2016; 32(2):11-24.

Karadağ E, Açıkgöz A, Balcı AG, Ünsal A, Kösgeroğlu N, Kaya Y, ve ark. Association between students' satisfaction and motivation in nursery and midwifery education. Health MED 2012; 6(12):421016.

Karataş, Z. Sosyal bilimlerde nitel araştırma yöntemleri. Manevi Temelli Sosyal Hizmet Araştırmaları Dergisi 2015;1(1):62-80.

Keeling J, Templeman J. An exploratory study: Student nurses' perceptions of professionalism.Nurse Education in Practice 2013;13:18-22

Kostak MA, Akarsu Ö, Ergül GD. Edirne Sağlık Yüksekokulu öğrencilerinin profili. Fırat Sağlık Hizmetleri Dergisi 2012;7(19):39-59.

Merriam SB. Nitel Araştırma Desen ve Uygulama İçin Bir Rehber. Turan S, editör. Ankara: Nobel Yayınlar1; 2013.p.205

Pınar ŞE, Yıldırım G, Duran Ö, Cesur B, Üstün Z, Güler E. Ana Çocuk Sağlığı Hizmetlerinde Kilit Rolde Olan Ebe Adaylarının Güdülenmeleri Yeterli mi? Bir 
Anket Çalışması. Hemşirelikte Eğitim ve Araştırma Dergisi 2014;11 (3): 22-31.

Reiger K. Domination or mutual recognition? Professional subjectivity in midwifery and obstetrics. Social Theory Health 2008; 6:132-47.

Sabancıoğulları S, Doğan S. Profesyonel Kimlik Gelişimi ve Hemşirelik. Anadolu Hemşirelik ve Sağlık Bilimleri Dergisi 2012;15(4): 275-82.

Sert E, Erkal Y, Tuna Oran N. Ebelikte Roy Adaptasyon Modelinin Antenatal Değerlendirmede Kullanımı. Gümüşhane University Journal of Health Sciences, 2014;3(4): 1147-60.

Seviğ Ü, Başer M. Güler H. Yurdakul M. Türkiye'de tıp-sağlık bilimleri alanında eğitim ve insan gücü planlaması "ebe insan gücü: Mevcut durum ve 2013 yılı vizyonu". Üniversitelerarası Kurul Tıp Sağlık Bilimleri Eğitim Konseyi, Ebe İnsan Gücü Planlama Komisyonu Çalışma Raporu, 2008.

Shaw HK, Degazon C. Integrating the core professional values of nursing: a profession, not just a career. J Cult Divers 2008;15(1):44-50.

T.C. Resmi Gazete. 6514 Sayılı Sağlık Bakanlığı ve Bağlı Kuruluşlarının Teşkilat ve Görevleri Hakkında Kanun Hükmünde Kararname ile Bazı kanunlarda Değişiklik Yapılmasına Dair Kanun, 2014.

Tekin Kaya N, Bilgin S. Çankırı İl Merkezinde Birinci Basamak Sağlık Kuruluşlarında Çalışan Ebe ve
Hemşirelerde İş Doyumu Düzeyi Ve Etkileyen Faktörlerin Değerlendirilmesi. Hacettepe Üniversitesi Sağlık Bilimleri Fakültesi Dergisi 2015; 1(1): 1-23.

Türkiye İstatistik Kurumu. İşgücü İstatistikleri, 2017

Ünsar S, Akgün Kostak M, Kurt S, Erol Ö. Hemşirelerin Kendini Gerçekleştirme Düzeyleri ve Etkileyen Etmenler, DEUHYO ED 2011;4(1):2-6.

Winch C. What do teachers need to know about teaching? A critical examination of the occupational knowledge of teachers. Journal of Educational Studies 2004;52 (2):180-96.

Yıldırım A, Şimşek H. Sosyal Bilimlerde Nitel Araştırma Yöntemleri. 10. Baskı. Ankara: Seçkin Yayıncılık; 2016. p.289-98.

Yılmaz FT, Şen HT, Demirkaya F. Hemşirelerin ve Ebelerin Mesleklerini Algılama Biçimleri ve Gelecekten Beklentileri. Sağlık ve Hemşirelik Yönetim Dergisi 2014; 3(1): 130-9.

Yurtsal ZB, Biçer S, Duran Ö, Şahin A, Arslan M, Yavrucu Ö. Sağlık Bilimleri Fakültesi ebelik 1. ve 4. sınıf öğrencilerinin mesleğe ilişkin görüşlerinin belirlenmesi. Erciyes Üniversitesi Sağlık Bilimleri Fakültesi Dergisi 2014;2(2):15-25 